\title{
Nuori Voima kirjallisena aikakauslehtenä 1930-luvulla
}

Kirjallisuutemme vuosikymmenien saatossa on erityisesti sodanjälkeisillä 1920- ja 1940-luvuilla vahvasti lyyrinen perusvire. Aikakauslehti Nuori Voima, jossa useimmat aloittelevat kirjailijat saivat ensimmäisen puheenvuoronsa, on tässä suhteessa todellinen 'ilmapuntari". 1920-luvun suuri lyyrinen uudistus oli odottamaton ja hämmentävä kaikille muille paitsi Nuoren Voiman lukijoille. Uuden proosan edustajia alkoi Nuoren Voiman palstoille ilmaantua vasta 20-luvun puolimaissa, kun Pentti Haanpää, Unto Seppänen ja Toivo Pekkanen julkaisivat ensimmäiset novellinsa. 1930-luvun taite oli taas varsin lyyrinen, mutta kymmenluvun keskivaiheilla ilmestyi lehteen myös uusia proosakirjailijoita. Vuosikymmenen loppupuolella lyriikka valtasi uudestaan alaa.

Tulenkantajapolven jälkeinen nuori kirjailijajoukko etsi tietään vähän toisin muodoin kuin heitä aikaisempi ryhmä. Nuoren Voiman Liiton toiminta oli tosin jatkuvasti vilkasta, ja 30-luvun alussa perustettu henkevä Kerho 33 antoi mahdollisuuksia kirjallisten ongelmien yhteiseen pohdiskeluun, mutta uusilla kynänkäyttäjillä ei kuitenkaan ollut tulemisessaan sellaista kiinteän ryhmän antamaa tukea kuin kymmenen vuotta aikaisemmin. Kustantajakin tarjosi apuaan. Yhteisvoimin julkaistiin antologia Nuoret runoilijat 1934, samanlainen nuoren lyriikan katselmus kuin vuosina 1924 ja 1926, mutta nyt oli mukana sellaisiakin runoilijoita, jotka eivät olleet Liiton jäseniä ja jotka olivat perin vähän aktiivisia Nuoren Voiman avustajinakin. 1920-luvulla lyriikan uudistus oli tapahtunut juuri Nuoren Voiman kirjalliseen harrastuspiiriin kuuluneiden runoilijoiden toimesta. Seuraavalla kymmenluvulla uudet kirjailijat eivät enää kuulu niin kiinteästi lehden ja Liiton piiriin. Nuori Voima ei ole heille pohjattoman innostuksen lähde, eikä sillä ole sitä suuren yhdistävän tekijän merki- 
tystä kuin aikaisemmalle kirjailijapolvelle. Mutta sen keskeistä asemaa kirjallisen kasvun harjoituspaikkana ei nytkään sovi kieltää.

Tulenkantajapolven produktiivisin runoilija oli Elina Vaara, jonka ensimmäinen runo painettiin Nuoressa Voimassa vuonna 1918. Vajaat kymmenen vuotta myöhemmin julkaisi ensimmäiset harjoitelmansa Saima Harmaja, joka 1930-luvulla edusti laadullisesti Elina Vaaran naisellista linjaa lehdessä. Vuoden 1927 jälkeen kului runsaat kymmenen vuotta seuraavan merkittävän naisrunoilijan ensiesiintymiseen. Talvisodan kynnyksellä julkaistiin ensimmäiset Aila Meriluodon runot tekijän ollessa 15 -vuotias. Vertailun vuoksi sopii majnita, että Elina Vaara ja Saima Harmaja olivat vastaavassa vaiheessaan 14-vuotiaita.

Saima Harmaja julkaisi lehdessä kaksikymmentä runoa kymmenvuotisen kirjailijakautensa aikana, niistä suurimman osan ennen esikoiskokoelmaa Huhtikuu (1932). Kuitenkin vain neljä runoa sellaisenaan kelpasi painettuun kokoelmaan, vaikka teemat ovat usein samoja. Saima Harmajan useimmissa varhaiskauden runoissa on kevätkesän kuulakasta vaaleutta. Kahdesti on huhtikuu innoittanut häntä, ja lisäksi sellaiset runot kuin "Huhtikuun sade", "Kevätilta" liittyvät tematiikaltaan samaan aihepiiriin. Runoilijan pakottavaa luomisen kaipuuta ja hehkuvaa kasvamisen tarvetta ilmentävät nuorelle tytölle harvinaisen intensiivisellä tavalla runot "Hurmio" ja "Tuska". Hänen runoilijanlaadussaan on jo varhaiskaudella paljon mietiskeleviä piirteitä, mutta nekin projisioituvat usein luontoon nïn kuin runossa "Contemplaatio". Saima Harmajan suhde elämään on tyttömäisistä piirteistään huolimatta totisempi kuin Elina Vaaran siitäkin huolimatta, että molemmat hakevat luonnosta tasapainoa ja eheyttä. Toistuva sairasteleminen jo kouluikäisenä on vienyt nuoren runoilijatytön pitkinä yksinäisyyden kausina syvempiin mietiskelyihin kuin tuona ikäkautena yleensä on tavallista.

Lukuun ottamatta erästä matkakuvausta Tartosta Saima Harmaja kirjoitti Nuoreen Voimaan yksinomaan runoja. Viimeinen runo oli vuoden 1937 viidenteen numeroon painettu samana keväänä kirjoitettu, jo kuoleman aavisteluja kätkevä 'Kaukainen ranta". Runon ohessa olivat Mika Waltarin kauniit jäähyväissanat. (1937: 156.) Myöhemmin oli lehdessä otteita Saima Harmajan julkaistusta päiväkirjasta, ja vuonna 1953 kiinnitettiin huomiota hänen syntymänsä 40-vuotispäivään. 
Unto Koskelan ainoa Nuoressa Voimassa julkaistu runo "Hyljätty jumala" oli samassa vuoden 1927 numerossa kuin Saima Harmajan ensi yritelmät. — Reino Rauanheimon ja Martti Merenmaan muutamat runot ja novellit 1930-luvun taitteessa ansaitsevat myös maininnan, vaikka heidän esikoisteoksensa olivat ilmestyneet jo aikaisemmin.

Enemmän huomiota kannattaa sen sijaan kiinnittää seuraavaan uuteen kynänkäyttäjään, Viljo Kajavaan. Ne viisi perin vaatimatonta runoa, jotka hän vuosina 1930 ja 1931 julkaisi, eivät tosin anna mitään ennakkokuvaa hänen myöhemmin niin laajasta tuotannostaan. Kaikki Nuoressa Voimassa julkaistut runot ovat ennen Rakentajat kokoelman (1935) ilmestymistä painettuja, eikä yksikään viidestä runosta kelvannut esikoiskokoelmaan. Viljo Kajava esiintyi lehdessä omalla nimellään; vain vuoden 1930 syksyllä hän otti osaa runokilpailuun nimimerkillä Mauri. Runo "Radio" saikin kunniamaininnan. Nimimerkkien käyttö ei ylipäätään enää 30-luvulla ollut niin suosittua kuin vuosikymmentä aikaisemmin.

Viljo Kajavan runot ovat yhtä lukuun ottamatta vapaamittaisia. Luonnonkuvat valtaavat runoissa "Kevät" ja "Syksy tulee" lyyrikon fantasian. Kunniamaininnan saaneen "Radio" runon perusilme on humoristinen. "Japanilaisessa fantasiassa" on rakkausaihe ja "Vieläkö" runossa ihmisen kärsimystä ja uskoa parempaan tulevaisuuteen. Viljo Kajavan rikasta ja moni-ilmeistä runoilijapersoonallisuutta nämä runot eivät kuitenkaan paljon valota huolimatta erilaisista aiheistaan. Koska hänen harrastusnäytekokoelmansa herätti suurta huomiota ja lupasi tekijälleen hyvää tulevaisuutta kirjallisissa yrityksissä, tuntuu oudolta, ettei se rohkaissut vilkkaampaan julkaisutoimintaan nuorison omassa lehdessä. Kajavan kokoelma oli näet "varsin lupaava rohkeudessaan ja erikoisuudessaan". (1930: 60.) Lausunnon antaja oli Mika Waltari, joka toimi harrastusnäytteiden arvostelijana vuosikymmenen vaihteessa.

Oiva Paloheimon nimi sen sijaan tuli lehden lukijoille paljon tutummaksi jo ennen hänen esikoiskokoelmaansa Vaeltava laulaja (1935). Varhaisin runo "Pieni balladi" julkaistiin samana vuonna kuin Viljo Kajavan ensimmäinen runo, ja vuodesta 1930 lukien painettiin Nuoreen Voimaan viiden vuoden aikana kaikkiaan kolmetoista Paloheimon runoa. Hänenkin innostuksensa näkyy loppuneen tähän, koska esikoiskokoelman jälkeen lehdessä on vain kolme runoa ja yksi novelli. Paloheimon nimi esiintyy sittemmin taajaan lehden arvostelu- 
osastossa, ja hänen kirjalliseen tuotantoonsa on kiinnitetty tutkivaakin huomiota. Kirjailija itsekin on laventanut kiinnostustaan ulkopuolelle varsinaisen kaunokirjallisuuden. Hän kirjoitti näet sodanjälkeisestä kirjallisuuden kehityksestä (1944: 2: 27) sekä kirjailijasta ja politiikasta (1945: 4: 8).

Oiva Paloheimo on myöhemmin kirjailijatyössään etääntynyt lyriikasta, mutta Nuoreen Voimaan hän kirjoitti enimmäkseen runoja. Antologiassa Nuoret runoilijat 1934 oli ennen julkaistuista kuitenkin vain kaksi runoa: "Nocturno" ja "Margaret". Näistäkin runoilija säälimättömällä kädellä pyyhki säkeistöjä pois ja typisteli niitä muutenkin. Niinpä viimeksi mainitun runon neljästätoista säkeistöstä pääsi mukaan vain yhdeksän. Tässä lyhennetyssä asussaan se on myös Vaeltavassa laulajassa. Paloheimon varhaisten runojen tarkastelija joutuu perin neuvottomaksi, jos hän ottaa tehtäväkseen hakea niistä yhtenäistä elämystaustaa. Niinpä luonto, josta nuori runoilija usein saa ensimmäiset ja helpoimmin antautuvat lyyriset kuvansa, tuntuu puhuneen melkein mykkää kieltä Oiva Paloheimon nuoruudenrunolle. Muutenkin nuori lyyrikko suhtautuu aiheistoonsa perin oikullisesti. Mika Waltari sanoo hänen runojaan "omintakeisiksi" arvostellessaan harrastusnäytekokoelmaa. (1929: 220.) Totta onkin, että Paloheimo on noudatellut julkaisemissaan runoissa niin yksilöllisiä linjoja, että on vaikea löytää mitään teemaa, joka viittaisi hänen tulevan kirjailijakuvansa hallitseviin piirteisiin. Hän on ikään kuin siepannut aiheet lennosta, ja runoissa on usein improvisoitu sävy sekä ilmeisen vaivattomasti rientävä säetaituruus. "Elämän herääminen" (1932) todistaa kyllä nuoren runoilijan miettineen jo ennen esikoiskokoelmaa elämänfilosofisiakin kysymyksiä. Jonkinlainen epätodellinen suhtautuminen elämään, suorastaan pako todellisuudesta, näyttää kiehtoneen 1930-luvun alussa runoilijan mielikuvitusta. Nuoruuden pessimismikään ei ole vierasta "Legenda surusta" ja "Ilon ja surun tori" runojen kirjoittajalle. Edelleen kuolema näyttää olleen läheinen aihe, ja eräänlainen vaimea uskonnollinen haaveellisuus hallitsee muutamia runoja. Jotkut legendat ja balladit kertovat kirjoittajansa varhaisesta mielenkiinnosta eepillis-draamallista runomuotoa kohtaan.

Suuren lyriikan pulaa valitettiin aivan yleisesti 1930-luvun alussa, vaikka useimmat kymmenluvun proosakirjailijoistakin aloittivat lyyrikkoina. Tulenkantajat heittivät vielä varjonsa uuden vuosikymme- 
nen puolelle. Heitä sekä ihailtiin että arvosteltiin, mutta heihin turvauduttiin, kun tienhaara tuntui olevan edessä. Lauri Viljanen epäilee Riku Sarkolalle antamassaan haastattelulausunnossa, että tulenkantajien etääntyminen todellisuudesta tuskin tuntuisi 30-luvulla onnelliselta. Niinpä hän jääkin odottamaan, että kirjalliseen ilmaisuun tulisi "uusi, rohkea realismi, johon elävä runoilijantunne antaa valoa ja lämpöä". (1933: 40.) Tämän haastattelun jälkeen Riku Sarkola antoi puheenvuoron muutamille nuorille kirjailijoille, joista useimmat valittavat syvästi kirjallista hajanaisuutta. Saima Harmaja odotti enemmän henkevyyttä ja kulttuuria: "Moderni kirjallisuutemme on väsyttävän täynnä kehittymättömiä, matalasti ajattelevia ihmisiä. Kirjailijoilla ei tunnu olevan mitään mielenkiintoa kultivoitunutta, korkealle kehittynyttä sielua kohtaan, ikäänkuin sellaisessa ei olisi enää mitään psykologisesti eriteltävää." (1933: 74.) Oiva Paloheimo taas halusi uutta vallankumousta tulenkantajien tapaan: "Vallankumousta! Uutta vallankumousta! Meillä kaivataan ehdottomasti vakavaa, pinnan alle pyrkivää ihmistuntemusta ja rehellistä yhteiskunnallista realismia. - Kansalliskirjallisuudessamme on tällä hetkellä silmäänpistävä aukko, joka olisi täytettävä, ettei jälkipolven tarvitsisi huolehtia meidän historiastamme." (1933: 74.)

Riku Sarkolan haastattelu saa tarkastelijan silmän terävöitymään uuteen harrastusalaan. Uuden vuosikymmenen alussa tekevät myös sanomalehtimiehet tuloaan Nuoren Voiman kirjalliselle parnassolle. Tosin useimmat heistä aloittavat kaunokirjailijoina. Niinpä Sarkolankin harrastelu jakaantuu kaunokirjallisuuden, kirjallisuudenhistorian ja kasvatuksen kesken. Jäsenmerkkinsä hänkin sentään lunasti runosikermällä. Sarkolan esikoiskokoelma Säikähtyneitä pilvï̈ (1931) ilmestyi samana vuonna kuin hänen ainoa runonsa "Kyynel" julkaistiin Nuoressa Voimassa.

Uusia runoilijoita ilmaantui lehden palstoille kaikesta huolimatta, vaikka he eivät perin tuotteliaita olleetkaan. Vuonna 1931 oli vuorossa Jaakko Haavio. Hänen pari runoaan ja kaksi jouluaiheista hartauskirjoitustaan eivät tosin todistaneet varsin suurta aktiivisuutta. Jaakko Haavio oli liittynyt Nuoren Voiman Liittoon jo koulupoikana, ja harrastusnäytekokoelmassa oli eräiden kielitieteellistä kiinnostusta osoittavien näytteiden lisäksi seitsemän "sangen omintakeista runoa", niin kuin Ilmari Jäämaa sanoi. (1922: 504.) Julkinen esiintyminen jäi kuitenkin seuraavan vuosikymmenen puolelle, 
ja esikoiskokoelmakin oli vasta vuoden 1933 satoa. Nuoressa Voimassa julkaistut kaunokirjalliset tuotteet kuuluvat joulun tienoon aiheistoon, josta Jaakko Haavio myöhemminkin on saanut paljon innoitusta.

Kun Heikki Asunta vuonna 1932 julkaisi lehdessä ensimmäisen I'unonsa "Tuhkimon laulu", oli hänen esikoiskokoelmansa Mustaa ja kultaa ilmestynyt jo kolme vuotta aikaisemmin. Lisäksi häneltä oli sen jälkeen tullut kaksi muuta kokoelmaa. Tähdellistä on todeta, että Heikki Asunta ei kuulunut Nuoren Voiman Liittoon. Tulenkantajaaikojen tiiviiseen ryhmittymiseen ei enää päästä. - Asunnan runoja oli lehdessä 30-luvun alussa kolme ja niiden lisäksi yksi novelli. Runoissaan Asunta osoitti mieltymyksensä balladinomaiseen kerrontaan ja merimieselämään, jotka ovat keskeisiä hänen myöhemmässäkin lyriikassaan.

Erkki Vuorela julkaisi ahkerasti vuodesta 1933 alkaen runojaan Nuoressa Voimassa; esikoiskokoelma Hiljainen runo ilmestyi viisi vuotta myöhemmin. Hänen myöhempää tuotantoaan ei kuitenkaan käy arvioiminen ahkeran matkaanlähdön perusteella, koska Vuorelan kirjallinen työ on sen jälkeen hajonnut moneen suuntaan. Nuoressa Voimassa julkaistut runot ovat usein herkkiä luonnonkuvauksia tai mietelyriikan alaan kuuluvia. "Aurinkolaulu", "Kesän ovella", "Iltalaulu" ja "Iltatunnelma" todistavat läheisestä suhteesta luontoon. Kaiken kaikkiaan runojen perussointi vastaa esikoiskokoelman nimeä.

Runoja julkaisi myös Helvi Hämäläinen Nuoressa Voimassa 1930luvun alussa. Jo vuonna 1926 hänet oli hyväksytty Nuomen Voiman Liittoon laajan runokokoelman nojalla, jonka Erkki Vala arvosteli hyvin omaperäiseksi. (1926: 472.) Harrastusnäytekokoelmassa oli käytetty taitavasti vanhaa kansanomaista runomittaa, ja se oli perin harvinaista tulenkantajien aikakaudella. Runoilija siirtyi seuraavalla kymmenluvulla vapaaseen mittaan. Helvi Hämäläisen ensimmäinen romaani Hyväntekijä (1930) oli jo silloin ilmestynyt, ja 1930-luvun alku oli hänen proosailmaisulleen muutenkin perin tuotteliasta aikaa. Kustannussopimuksia ei kuitenkaan syntynyt, niin kuin kirjailija itse mainitsee eräässä Paavo Aarniolle antamassaan haastattelussa. (1934: 110.) Pulakausi tuntui kiristävänä ensiksi henkisen ravinnon alalla. Helvi Hämäläinen julkaisi myöhemmin myös runokokoelmia, vaikka hänen pääasiallisin tuotantonsa onkin proosaa. Romaanikirjailijat olivat Nuoren Voiman avustajina jopa novellisteja huonommassa ase- 
massa sen takia, ettei heidän laajoja esityksiään tilanpuutteen tähden voitu lehdessä julkaista niin usein kuin palstatilaa vähemmän vieviä runoja.

Kiinnostava uusi kirjallinen nimi, Tatu Vaaskivi, ilmestyi vuonna 1934 lehden palstoille. Hän oli Nuoren Voiman lukijoille lähinnä kirjallisuudentutkija, joka selosti mm. Sillanpään elämää (1936: 176) ja 1920-luvun runoutta (1936: 109), mutta tunsi kiinnostusta myös runontekoon. "Sardanapaluksen kuolema" on koristeellinen, orientaalisen raskain runokuvin esitetty elämäntyhjyyttä tulkitseva filosofinen runo. Itämaisen tuhlaileva kuvien loisteliaisuus antaa aiheen otaksua, että Vaaskivi oli haltioituneena tutustunut tulenkantajien eksotiikkaan. Esitellessään omalle ajalleen lyriikkamme uudistajia hän sanoo Hurmioituneiden kasvojen olevan niin kyllästetty itämaisen loistavilla kuvilla ja kukkivilla vertauksilla, ettei sitä ennen "suomalainen runoilija ollut tuolla tavoin tuhlannut koko palettiaan". (1936: 110.) - Ilmeisesti Tatu Vaaskivi sillä kertaa arvioi laatunsa lähinnä esteettiseksi ja katsoi itsensä kirjallisuushistorioitsijaksi, koska hän pyrki Liittoon neljällä esseellä. Ammattinsa hän kyllä sanoi siinä yhteydessä olevan kirjailijan. Esseitä ei ainakaan sillä erää julkaistu, vaikka Paavo Aarnio arvioi näytteen olevan "erittäin korkeatasoinen ja hienostunut". (1936: 24.)

Heikki Jylhän ja Pentti Lahden runon sato jäi varsin vähäiseksi niin Nuoren Voiman palstoilla kuin laajemmassa kirjallisessa julkisuudessa. - Kalervo Hortamo on yltänyt pitemmälle. Yksinäisten korpiseutujen kuvaaja ilmestyi lehteen vuonna 1936, mutta julkaisi siinä kaikkiaan vain kolme runoa. Yhteiskokoelmaan Nuoret runoilijat 1943 sisältyvässä sarjassaan ja esikoiskokoelmassa Sydänmaı (1947) hän on jatkanut samaa korpikuvauksen linjaa.

Alkuperäisten lyyrikkonerojen luvattua aikaa ei 1930-luku näytä olevan. Lehden palstoille ilmaantuu noina aikoina paljon toisen Iuokan kykyjä ja lahjakkaammatkin julkaisevat perin vähän. Kaikilla ei tunnu olevan edes päättävää kirjallista kunnianhimoa; runonteko oli muuten vain harrasteena. Mutta tavallaan alkusoittona uudelle lyyriselle kymmenluvulle on Aila Meriluodon ilmestyminen Nuoren Voiman kirjalliseksi avustajaksi vuonna 1939. Tosin hänkin julkaisi perin vähän, vain kaksi runoa: "Kuollut päivä" ja "Kotiinpaluu". Nuoren Voiman Liiton jäseneksi hän tuli vasta vuonna 1943, jolloin hän oli jo ehtinyt olla mukana yhteisantologiassa Nuoret runoilijat 
1943. - Mainitut runot eivät kuitenkaan sisältyneet kokoelmaan. "Kuollut päivä" paljastaa tumman pohjakerroksen nuoren runoilijatytön ajatusmaailmassa ja "Kotiinpaluussakin" on salattua vakavuutta heleän luonnontunnelman ja riemullisen kotiintulon päätteeksi. Aila Meriluodon runonäytteet herättivät valmiudellaan suurta huomiota, mikäli nimimerkki A. M-o on katsottava Kirjeenvaihtoosastossa nimenomaan hänelle kuuluvaksi. Toimitus ilmoittaa, että runot ovat "suoranainen yllätys", ja kehottaa kirjoittajaa kiinnittämään vakavaa huomiota lahjoihinsa. (1939: 169.) Samaan numeroon on painettu runo "Kuollut päivä".

Martta Haatasen pari novellia ja Tyyne-Maija Salmisen niin ikään kaksi kertomusta täydentävät 30-luvun kirjallisuuden kuvaa Nuoressa Voimassa. Haatasen novelli "Arvoitus" kertoo hänelle tutusta rautatienrakentajien elämästä, ja pienessä tunnelmakuvauksessa "Olin kerran" hän eläytyy herkästi vanhuksen resignoituneeseen elämäniltaan. — Salmisen "Taltta ja moukari" sekä "Pikku taiteilija" ovat kumpikin opettavia taiteilijatarinoita.

Kunnianhimoisiin kirjallisiin päämääriin ei nuori polvi omassa lehdessään 1930-luvulla kuitenkaan pyrkinyt niin määrätietoisesti kuin vuosikymmentä aikaisemmin. Saima Harmaja ja Oiva Paloheimo olivat tuotteliaimpia, vaikka esikoiskokoelman jälkeen heidänkin intonsa laimeni; heidän runonsa olivat myös taiteellisesti kirjallista lahjakkuutta osoittavia. Se, että lehti esikoiskokoelman jälkeen menetti heille merkitystään, oli vain luonnollista, koska se nuoren kynänkäyttäjän ensimmäisenä harjoituskenttänä oli silloin jo täyttänyt tehtävänsä.

Varttuneemman polven kirjailijoista olivat Nuoren Voiman aktiivisessa toimitustyössä mukana Arvi Kivimaa ja Urho Karhumäki, jotka molemmat olivat jonkun aikaa vastuunalaisesti lehden ja Liiton johdossakin. Arvi Kivimaa jatkoi samaa monipuolisen hengenviljelyn linjaa, jota hän oli jo 20-luvulla noudattanut. Hänen kuusi alkuperäistä runoaan julkaistiin lehdessä 1930-luvulla. Sitä paitsi hän antoi näytteen kirjallishistoriallisesta tutkimuksestaan julkaistessaan esittelyn Urho Karhumäestä (1937: 5), joka Berliinin olympiakisoissa oli edellisenä vuonna saanut taidekilpailun palkinnon ja josta hiljan. oli tullut Nuoren Voiman Liiton ylijohtaja. Artikkeli "Kirjat, joihin palaamme" (1936: 257) taas oli alun perin laajalle yleisölle tarkoitettu radioesitelmä, ja siinä käsitellyt kirjat esiteltiin Raamatusta ja 
eräistä klassillisista kaunokirjallisista teoksista aina puhelinluetteloon ja keittokirjaan asti!

Mielenkiintoisinta Arvi Kivimaan toimittajantyössä on erityisesti 1930-luvun kulttuuripoliittisten olojen tutkijalle se kasvatuksellinen nuorison ohjaus, jota hän harjoitti lähinnä päätoimittajana ja vt. ylijohtajana. Näissä kirjoituksissaan Arvi Kivimaa ei ollut suoraviivainen opettaja ja kasvattaja, vaan enemmänkin filosofisen mietiskelevä aatteen mies, joka samalla oli hienostunut ja tarkkavaistoinen kulttuuripoliittisten näköalojen tähystelijä. Pääkirjoituksessaan "Ainoa tie" (1936: 35) hän kirjoittaa siitä 30-luvun henkisestä kuohumistilasta, joka pitkiksi ajoiksi eteenpäin painoi "poltinmerkin" kymmenluvun kulttuurielämään. "Elämme henkisen sekasorron kautta. Se on täynnä kamppailua ja levottomuutta. Ajan paine kohtaa ankarana varsinkin niitä, jotka yrittävät toimia henkisen vartiopalveluksen etulinjoilla. On jo kuultu paljon epäilyn ja toivottomuuden ääniä; on väitetty, että länsimainen kulttuuri on menossa hautaansa ; tahtovat ja taistelevatkin miehet ovat sanoneet, että kulttuurin elinmahdollisuudet pienenevät pienenemistään. Miten käy nuorison? kysytään. Onko syytä ruokkia toivoa ja rohkeata elämänuskoa, kun tulevaisuus on pimeä ja kaikelta siltä, mikä tekee elämän elämäksi, tahdotaan riistää sen merkitys ja arvo?" - Kivimaa on kuitenkin kulttuurioptimisti ja hän osoittaa nuorisolle tien, ainoan tien, joka vie päämäärään: elämänrohkeuden ja puhtaan tahdon tien. Lisäksi hän toteaa, että nuodinmukainen "mustamaalaus" ei aina palvele totuutta. Ennenkin on ollut vaikeuksia, mutta ne on voitettu.

Arvi Kivimaan artikkeli "Ainoa tie" kuvastaa osaltaan 30-luvun yleistä levottomuutta. Runoilija ja kulttuurimatkailija näki ja tunsi Euroopan kuumeisen varustautumisen uhkaavan nimenomaan henkistä kehitystä. Urho Karhumälki ei ollut samalla tavalla kulttuuripoliittisten 'näkymien väsymätön tarkkailija. Hän oli kirjailijanlaadultaan rauhallisemmin eepillinen ja järjestömiehenä jykevämmin omalla maaperällä; nuorisoseurahenkinen aatteen mies, joka käytännöllisten pyrkimysten tietä ohjasi nuorisoa sen harrastuksissa. "Olin enemmän kasvattaja kuin opettaja", hän luonnehtii omaa opettajantointaan Paavo Aarniolle antamassaan haastattelussa. (1936: 269.) Hän pysytteli usein oman Liiton piirissä ja yritti tehostaa sen toimintamuotoja; näin nimenomaan artikkeleissa "Nuori voima - elämän voima" (1937:3) ja "Nuoren Voiman Liitto ja maaseutu" 
(1937: 44). Hänen tehtäväkseen jäikin luotsata lehti ja Liitto sotaajan karikkojen halki silloin, kun henkinen toiminta näytti olevan kokonaan lamassa. - Kaunokirjailijana Urho Karhumäki julkaisi lehdessä varsin vähän. Vuosikymmenen lopulla painettiin pari novellia: "Kaksi kulkijaa tiellä" ja "Kolmion sivujen summa".

Ylimalkainenkin vertailu osoittaa, että nuoret kynänkäyttäjät eivät 1930-luvulla julkaisseet tuotteitaan Nuoressa Voimassa 1ähimainkaan yhtä aktiivisesti kuin vastaavassa kehitysvaiheessa olevat 1920-luvulla. Kooltaan lehti oli kyllä komeampi vuodesta 1929 aina 30-luvun puoliväliin asti. Siihen tulee enemmän kuvia; jopa kokonaiset kuva-aukeamat tulevat muotiin. Uudet harrastukset, voimistelu ja urheilu, sekä laajamittainen nuorisotyö vaativat runsaasti sivuja. Toimitetaan osastoja, joihin ei ole korkeasti kirjallisia pääsyvaatimuksia. Koululaiset saavat harrastuksilleen tukea enemmän kuin ennen. Helsingin Toverikuntaliitto -osastossa selostetaan lähinnä toverikuntien työmuotoja. Kirjallishistoriallisesti kiintoisana vilahtaa lukrijan silmien ohi lukuisien teeiltaselostusten joukossa vain joku Matti Kuusen tai Eino Kauppisen runo sekä tieto Aale Tynnin voitosta runokilpailussa. - SOU (Suomen oppikoulujen urheilijat) toimii ripeästi: osaston täyttävät pitkät tulosluettelot ja kilpailuselostukset. Nuoret kirjailijat eivät enää ole sellaisen huomion kohteena kuin 20-luvulla, jolloin nyrkkeilevä Yrjö Jylhä joka tapauksessa oli enemmän runoilija kuin nyrkkeilijä. Koulumaailma -osasto on todellinen lehti lehdessä ja sekin sisältää pääasiassa selostuksia. Uusi taidemuoto, elokuva, ilmestyy kilpailemaan kirjojen kanssa. Hyviä harrastuksia on paljon: postimerkki- ja šakkiosastot laajenevat. Tosin vuosikymmenen lopulla perustetaan uusi osasto, Nuorten oma osasto, erityisesti kirjallisia harrastelijoita varten. Siinä kilpaillaan säännöllisesti parhaista kirjoituksista ja runoista, mutta intoa ei oikein riitä. Tämän osaston avustajista vain Aila Meriluoto on yltänyt kirjallisiin laakereihin.

Useimmat tulenkantajat pysyivät uskollisina lehdelleen. Paavo Aarnion haastattelusarja 'Nuoren Voiman Liiton merkkihenkilöitä" teki heistä tunnettuja myös yksityishenkilöinä. Edellisellä kymmenluvulla kirjallisen asemansa valloittaneet olivat myös valmiita opastamaan nuorta polvea. Mika Waltarin työ kirjallisen harrastuspiirin puheenjohtajana on huomattava, koska hän tässä ominaisuudessa joutui arvostelemaan harrastusnäytteitä. 
Kirjallisuuden esittely ei ollut niin monipuolista kuin 1920 luvulla. Vanhemman polven suomalaista kaunokirjallisuutta ei juuri painettu uudestaan eikä kirjailijoita esitelty. Nuorten kirjailijoiden keskuudesta ei liioin noussut sellaisia kääntäjiä kuin edellisen kymmenluvun Elina Vaara ja Yrjö Jylhä. Sen sijaan ensimmäiset kannuksensa hankkii nyt joukko myöhemmin tunnettuja lehtimiehiä, mutta heidän alueensa on pakostakin laajempi kuin kaunokirjallisuus.

Käännöskirjallisuuden parhaita nimiä sisälsivät osastot Mestarinovelli ja Kuuluisista kirjoista. Näihin sarjoihin otettiin vain klassikoita. Nimisarja onkin monipuolinen ja kunnioitusta herättävä: Herman Bang, Björnstjerne Björnson, Eve Curie, Alphonse Daudet, Charles Dickens, Anatole France, John Galsworthy, Nikolai Gogol, Knut Hamsun, Thomas Hardy, Werner von Heidenstam, Rudyard Kipling, Selma Lagerlöf, Guy de Maupassant, Prosper Mérimée, Anton Tšehov ja Mark Twain. Klassilliseen kirjallisuuteen oli siis ainakin proosan osalta mahdollisuus tutustua. Englantilaista runoutta esitteli vuosilkymmenen alkupuolella Yrjö Jylhä ja antiikin kirjallisuutta V. Arti luovuttamalla näytteitä Ovidiuksen Muodonmuutoksista, joka myöhemmin ilmestyi kirjana. Uutta ruotsalaista kirjallisuutta ei paljon harrastettu, ei liioin saksalaista. Varsin tilapäisluonteista oli niin ikään ranskalaiseen kirjallisuuteen kohdistunut kiinnostus. Ikkunat Eurooppaan sulkeutuivat. Suomenruotsalainen kirjallisuus ei myöskään ollut muodissa. Joitakin Wecksellin runoja sentään saatiin lukea kymmenluvun alkupuoliskolla Reino Hirvisepän suomentamina.

Vuosikymmenen kirjallinen kuva ei kuitenkaan Nuoren Voiman sivuilta käsin ole vielä täysin valaistu. On muistettava, että nyt elettiin enemmänkin ideologisten keskustelujen ja väittelyjen kuin kirjallisen ilmaisun kautta. Puhuttiin vähintään yhtä paljon kuin kirjoitettiin. Tulenkantajilla oli ollut kirjallinen keskusteluryhmänsä, mutta se pysyi verraten pienenä sisärenkaan piirissä. 1930-luvun alussa perustettiin Kerho 33, joka sekin alussa oli suppea keskustelukerho ja jonka vilkkaasta toiminnasta myöhemminkin hyötyivät pääasiassa helsinkiläiset. Mutta kerhossa käydyistä keskusteluista singahti sirunen myös Nuoren Voiman maaseutulukijoille, koska niistä julkaistiin säännöllisesti selostuksia. - 1930-luku oli voimakkaitten äärimmäisyyssuuntien vuosikymmen, ja se heijastui myös monella tavalla Nuoren Voiman Liiton ja Kerho $33: \mathrm{n}$ toiminnassa. Poliittisista varovai- 
suussyistä Nuori Voima lopetti vuonna 1936 Kerho 33:n kokousselostusten julkaisemisen, ja vielä saman vuoden lopulla se lakkasi olemasta myös Liiton äänenkannattaja. Kaikki tämä tapahtui kirjalliselta kannalta katsoen lehden vahingoksi. Ilmari Jäämaan kuolema vuonna 1934 oli jo kipeästi koskenut lehden ja Liiton elinvoiman hermoon. Hajaantumista tapahtui siis liian monella alueella, jotta ehjä ja voimakas rintama olisi voitu säilyttää.

Vaikeuksista huolimatta Nuori Voima kuitenkin yritti taistella kirjallisen vireytensä puolesta. Vaikka 30-luvun monipuolistunut kulttuuritoiminta ottikin runsaan määrän sivuja, jäi kirjallisuudenkin käyttöön sentään vielä tilaa. Vanhan tavan mukaan lehti pyrki antamaan myös teoreettista opastusta. Heti vuosikymmenen alussa julkaistiin Mika Waltarin artikkeli "Lennä Pegasos" (1932: 77), jossa "kaikille aloitteleville kynäilijöille" annettiin ohjeita yhtä hyvin runo- kuin proosamuotoisen taiteen luomisessa. Nuoressa Voimassa saamiensa herätteiden innoittamana kirjailija julkaisi vuonna 1935 teoksen Aiotko kirjaitijaksi?

Perin pessimistinen oli kuitenkin se yleinen tilanteenarviointi, jonka Waltari suoritti 30-luvun kirjallisesta tilasta artikkelissaan "Tämän päivän kirjallisuuden suuntaviivat". Hän totesi aluksi, että kirjallisuuden yleiskuva on ensi silmäyksellä "murheellinen, synkkä, lohduton ja yleensä sellainen, että tekisi mieli painaa pää piiloon pensaaseen sitä katsellessa". (1936: 5.) Suomen oloja tarkastellessaan hän yhdisti nuoren ja keski-ikäisenkin kirjailijapolven elämänmyönteisyyden puuttumisen poliittisiin ja taloudellisiin oloihin: "Meidän sukupolvemme, meidän aikamme on kokenut maailmansodan, se on kokenut hullun nousukauden ja hajoittavan talouspulan, se on kokenut nälän, työttömyyden ja köyhyyden, se on nähnyt parhaiden unelmiensa kerran toisensa jälkeen pettävän, se on nähnyt massojen nousevan suoraan huutoon polkemaan ihmiskunnan parhaat ja jaloimmat ajatukset vihan lokaan, mutta sittenkin meiltä kirjallisuudessa vaaditaan tiettyä, myönteistä elämänkäsitystä.” (1936: 5.) - Mutta Waltari ei ole toivoton ajatellessaan kirjallisuuden tulevaa kehitystä: "Niinpä kirjallisuuskin tänä päivänä kokee muodonvaihdoksen, joskin kokonaan toisella tavoin kuin maailmansodan hysteerisinä jälkivuosina. Jossakin syvällä pulppuaa luomisen syvä, tumma virta välittämättä toiselta puolen päivän rähinästä ja melusta tai toiselta puolen kiltistä, säyseästä sovinnaisuudesta. Rehellisyys, ehdoton totuuden pakko, arkipäivää suuremman elämänkokonaisuuden tajuaminen, 
mutta samalla myös katkera yksinäisyys lienevät ne ominaisuudet, jotka parhaiten luonnehtivat sitä kirjallisuutta, joka tästä päivästä jää elämään.” (1936: 6-7.)

Tulenkantajien vuosikymmenen romanttisista kauneuden unelmista oli näin palattu maan pinnalle. "Hurmioituneet kasvot" olivat saaneet ankaran päättäväisen ilmeen.

\section{Kerttu SaArenheimo: The part played by Nuori Voima as a literary periodical in the 1930s}

In Finnish literary life the 1920s were often called the decade of the torchbearer (tulenkantajat) whereas the 1930s were charaeterized by economic difficulties, political unrest and manifold disputes.

The periodical Nuori Voima, which often gave young writers their first opportunity to express themselves in public, did not play so central a rôle as "a maker of writers" in the thirties as it had done in the twenties.

A great lyrical revival took place in Finnish literature in the 1920s, largely the result of the work of those poets belonging to the Nuori Voima circle. In the 1930 s the periodical was able to publish the work of just a few really talented young writers, who later found a place in Finnish literature. Saima Harmaja, a. sensitive lyric poet who died young, published many fine descriptions of nature and philosophical poems concealing presentiments of death. In spite of his prolific later works Viljo Kajava, who in the 1930s continued the free verse tradition of the torch-bearers, was not much inclined to publish in the young people's periodical. The next new poet was Oiva Paloheimo who made considerable contributions to the paper, especially as a poet. He later abandoned poetry for prose. Prose writers were in a less favourable position since prose passages demanding much space could not be published owing to the small number of pages. It was for this reason that Helvi Hämäläinen, a well-known prose writer published poems in the periodical. Martta Haatanen and Tyyne-Maija Salminen had to content themselves with publishing short stories. Other familiar Finnisin writers who contributed to Nuori Voima during the 1930s are Jaakko Haavio, Heikki Asunta, Tatu Vaaskivi and Kalervo Hortamo. During the decade that preceded the war Aila Meriluoto began her writing and after the war made a great sensation with her more mature collections.

In the 1930s two writers of the older generation, Arvi Kivimaa and Urho Karhumäki took an active part in editing the paper. Arvi Kivimaa was a sensitive and highly cultivated person, who was able to provide the readers with information about foreign developments in the cultural field. There was a prevailing atmosphere of pessimism in cultural life and Kivimaa, especially in an article entitled "The only way" (Ainoa tie), did his best to stimulate his young readers. Mika Waltari was another who gave guidance to young writers and tried to explain the general state of literature in the 1930s. Even his outlook was not unduly optimistic, but he too urged his readers to rise above everyday materialism. 